\title{
CORPORATE GOVERNANCE DAN PENGARUHNYA TERHADAP KINERJA KEUANGAN PERUSAHAAN
}

\author{
Emilia Gie \\ Universitas Airlangga \\ Email: emi_gie@yahoo.co.id
}

\begin{abstract}
Application of corporate governance in the company is a way to handle the agency conflict that impact to company's financial performance The objective of this research is to analyses the impact of managerial ownership, board size, ownership concentration and debt toward financial performance that measured by ROE. The population of this research is the manufacturer companies which listed at Bursa Efek Indonesia (BEI) over the five years periods on 2009 until 2013. This research used purposive sampling method. The sample of this reseach consist of 90 companies that met the criteria. This study uses multiple regression analysis to see the contribution of each variable in influence financial performance of company. The results showed that : (1) managerial ownership is not significant to effect financial performance of company, (2) board size is not significant to effect financial performance of company, (3) ownership concentration is significant to effect financial performance of company, (4) debt is significant to effect financial performance of company
\end{abstract}

Keywords : corporate governance, financial performance of company, managerial ownership, board size, ownership concentration and debt. 


\begin{abstract}
Abstrak
Penerapan coporate governance perusahaan adalah cara untuk menangani konflik keagenan yang berdampak pada kinerja keuangan perusahaan. Tujuan dari penelitian ini adalah untuk menganalisis dampak kepemilikan manajerial, ukuran dewan, konsentrasi kepemilikan, dan utang terhadap kinerja keuangan yang diukur dengan ROE. Populasi penelitian ini adalah perusahaan produsen yang terdaftar di Bursa Efek Indonesia (BEI) selama periode lima tahun dari tahun 2009 hingga 2013. Penelitian ini menggunakan metode purposive sampling. Sampel penelitian ini terdiri dari 90 perusahaan yang memenuhi kriteria. Penelitian ini menggunakan analisis regresi berganda untuk melihat kontribusi masing-masing variabel dalam mempengaruhi kinerja keuangan perusahaan. Hasil penelitian menunjukkan bahwa: (1) kepemilikan manajerial tidak berpengaruh signifikan terhadap kinerja keuangan perusahaan, (2) ukuran dewan tidak berpengaruh signifikan terhadap kinerja keuangan perusahaan, (3) konsentrasi kepemilikan berpengaruh signifikan terhadap kinerja keuangan perusahaan, (4) hutang signifikan untuk mempengaruhi kinerja keuangan perusahaan
\end{abstract}

Kata kunci: corporate governance, tata kelola perusahaan, kinerja keuangan perusahaan, kepemilikan manajerial, ukuran dewan, konsentrasi kepemilikan, dan hutang. 


\section{PENDAHULUAN}

Corporate governance merupakan suatu sistem yang dapat mencegah terjadinya konflik keagenan. Manajer yang merupakan pengelola perusahaan memiliki peran yang penting dalam menjalankan corporate governance. Banyak yang mengatakan bahwa penerapan corporate governance di Indonesia lemah sehingga mendapat banyak perhatian dari pemerintah maupun investor. Lemahnya corporate governance salah satunya ditandai dengan tidak efektifnya peran dari manajer sebagai pengelola perusahaan (Mallin, 2007, dalam Martsila dan Meiranto, 2013). Manajer yang bertugas mengelola perusahaan tidak menjalankan fungsi dan tugasnya dengan baik sehingga tujuan yang diinginkan oleh para pemegang saham tidak dapat terpenuhi karena ketidakefektifan peran manajer. Ketidakefektifan peran manajer ini, menimbulkan konflik kepentingan di dalam perusahaan yang dapat dikurangi dengan suatu mekanisme yang dapat mengatasi kepentingan pemegang saham sebagai pemilik maupun kepentingan manajer sebagai pengelola. Mekanisme tersebut adalah mekanisme corporate governance. Faktor utama yang menjadi fokus corporate governance adalah manajemen perusahaan didasarkan pada kemampuan para pemimpin perusahaan dalam mengendalikan seluruh kegiatan perusahaan, baik internal maupun eksternal.

Penerapan corporate governance yang baik dapat meningkatkan kepercayaan pemegang saham dan kreditor terhadap perusahaan. Keterkaitan antara penerapan corporate governance dengan kinerja perusahaan adalah penerapan corporate governance yang baik akan membuat investor memberikan respon yang baik terhadap kinerja perusahaan dan dapat meningkatkan nilai pasar perusahan. Investor akan lebih mempercayakan investasinya pada perusahaan karena kinerjanya yang baik.

Dalam mekanisme corporate governance terdapat dimensi-dimensi corporate governance, yaitu kepemilikan manajerial, Kepemilikan institusional, Ukuran dewan komisaris, proporsi komisaris independen, konsentrasi kepemilikan dan proporsi utang (leverage).

Penelitian ini akan meneliti pengaruh corporate governance terhadap kinerja keuangan perusahaan yang terdaftar di BEI tahun 2009-2013 dan memiliki data mengenai komisaris, lembar saham yang dimiliki oleh pihak manajer dan jumlah lembar saham yang beredar, nilai aset total, nilai modal saham dan keuntungan pertahun. Variabel dependen dalam penelitian ini adalah kinerja keuangan perusahaan yang diukur dengan ROE. Variabel kontrol yang digunakan agar penelitian tidak meluas, yaitu : 1) komposisi aset perusahaan, 2) ukuran perusahaan. Penggunaan variabel kontrol ini untuk memastikan bahwa pengaruh corporate governance terhadap kinerja perusahaan tidak disebabkan adanya variabel dari faktor yang tersebut diatas, tetapi 
murni dipengaruhi oleh penerapan corporate governance pada perusahaan.

\section{LANDASAN TEORI}

\section{Teori Keagenan}

Dasar yang digunakan untuk memahami corporate governance adalah perspektif hubungan keagenan. Hubungan keagenan merupakan sebuah kontrak antara manajer dengan investor (Jansen dan Meckling, 1976). Konsep dari teori agensi ini didasari pada permasalahan agensi yang timbul ketika terpisahnya pengurusan suatu perusahaan dari kepemilikannya. Dengan adanya pemisahan antara kepemilikan dan pengendalian membuat adanya harapan investor agar manajer mampu mengelola uang yang diinvestasikan untuk menghasilkan returns. Eisenhardt (1989) mengungkapkan bahwa teori agensi menggunakan tiga asumsi sifat manusia yaitu: (1) manusia pada umumnya mementingkan diri sendiri, (2) manusia memiliki daya pikir terbatas mengenai persepsi masa mendatang, dan (3) manusia selalu menghindari risiko. Dari ketiga asumsi sifat dasar manusia tersebut maka manajer sebagai manusia akan bertindak mengutamakan kepentingannya sendiri.

Manajer yang paling banyak mengetahui tentang informasi internal dan prospek perusahaan di masa yang akan datang dibandingkan pemilik. Manajer berkewajiban memberikan sinyal kepada para pemegang saham (pemilik) mengenai informasi perusahaan dengan laporan keuangan yang berisi informasi akuntansi. Laporan keuangan sangat penting bagi pihak eksternal agar mereka mengetahui kinerja perusahaan dan dengan cepat serta tepat memutuskan untuk terus berinvestasi atau menarik kembali investasi mereka. Einsenhardt (1989) mengungkapkan bahwa teori keagenan ditekankan untuk mengatasi dua permasalahan yang dapat terjadi dalam hubungan kegenan. Pertama, masalah yang timbul pada saat (a) keinginan-keinginan dan tujuan-tujuan dari prinsipal dan agen berlawanan dan (b) suatu hal yang sulit atau mahal bagi prinsipal untuk melakukan verifikasi tentang apa yang benar-benar dilakukan oleh agen. Kedua, masalah pembagian risiko yang timbul pada saat prinsipal dan agen memiliki sikap yang berbeda terhadap risiko.

Investor merupakan "kelompok masyarakat ekonomi kelas atas, yang memiliki dana dan kekayaan jauh lebih banyak dari rata-rata penduduk biasa” (Rochbini, 2008 : 16). Investor sangat sensitif terhadap isu keamanan usaha sehingga dengan menerapkan corporate governance yang didasarkan teori keagenan maka sangat diharapkan agar bisa berfungsi sebagai alat untuk meyakinkan investor bahwa investasi mereka akan menghasilkan returns. Corporate governance berkaitan dengan bagaimana para manajer meyakinkan investor bahwa mereka akan memperoleh returns. 


\section{Corporate Governance}

Corporate governance merupakan efektivitas mekanisme yang bertujuan meminimalisasi konflik keagenan, dengan penekanan khusus pada mekanisme legal yang mencegah dilakukannya ekspropriasi atas pemegang saham minoritas (Johnson dkk, 2000). Corporate governance digunakan sebagai pedoman bagi manajer untuk mengelolah perusahaan. Manajer dapat membuat keputusan yang menguntungkan bagi pemangku kepentingan. Sehingga berdampak bagi peningkatan nilai perusahaan karena saham perusahaan banyak diminati oleh investor. Mekanisme corporate governance antara lain : kepemilikan manajerial, ukuran dewan komisaris, konsentrasi kepemilikan dan proporsi utang.

\section{Kinerja Keuangan Perusahaan}

Nilai dari sebuah perusahaan dapat dilihat dari kinerja perusahaan tersebut yang terdapat dalam laporan keuangan yang berisikan informasi akuntansi yang sangat berguna bagi investor. Laporan keuangan yang menggambarkan kinerja perusahaan harus berisikan semua informasi yang dibutuhkan investor sehingga investor dapat mengetahui kinerja masa yang akan mendatang bagi perusahaan. Berhasil atau tidaknya sebuah perusahaan dapat dilihat dari kinerja keuangan perusahaan dalam menghasilkan laba. Media yang dapat dipakai untuk melihat kondisi kesehatan perusahaan adalah laporan keuangan yang merupakan hasil akhir dari proses akuntansi. Dengan mengetahui kondisi keuangannya, perusahaan dapat membuat keputusan yang rasional. Keputusan yang benar sangat berdampak positif bagi kinerja perusahaan ke depannya sehingga dapat menarik perhatian dari investor untuk menanamkan modalnya. Investor cenderung lebih berkepentingan dengan keuntungan saat ini dan di masa yang akan datang. Para investor akan lebih berminat pada kondisi keuangan perusahaan yang dinilai sehat atau berkinerja baik. Sawir (2001) mengungkapkan bahwa ROE dapat memperlihatkan sejauh manakah perusahaan mengelola modal sendiri secara efektif, mengukur tingkat keuntungan dari investasi yang telah dilakukan pemilik modal sendiri atau pemegang saham perusahaan.

\section{Pengaruh Kepemilikan Manajerial terhadap Kinerja Keuangan Perusahaan}

Kepemilikan manajerial merupakan kepemilikan saham oleh pihak manajemen. Semakin besar kepemilikan saham oleh manajemen maka akan semakin berkurang kecenderungan manajemen dalam mengoptimalkan penggunaan sumber daya serta mengurangi biaya agensi karena perbedaan kepentingan (Jensen dan Meckling, 1976). Kepemilikan manajerial akan berpengaruh terhadap kinerja keuangan perusahaan. Dengan meningkatnya kepemilikan saham maka manajemen akan lebih giat meningkatkan kinerja keuangan perusahaan demi kepentingan pemegang saham 
termasuk pihak manajemen itu sendiri. Dengan meningkatnya kepemilikan saham oleh manajer, maka akan meningkatkan kinerja perusahaan.

H1 : Kepemilikan Manajerial berpengaruh signifikan terhadap Kinerja Keuangan Perusahaan

\section{Pengaruh Ukuran Dewan Komisaris terhadap Kinerja Keuangan Perusahaan}

Semakin banyak anggota dewan komisaris maka akan semakin buruk kinerja keuangan perusahaan. Hal ini disebabkan karena semakin banyak anggota dewan komisaris maka dalam menjalankan peran akan mengalami kendala. Koordinasi antar anggota dewan dalam proses pengambilan keputusan akan sangat sulit dilaksanakan dan prosesnya menjadi lambat karena sulitnya kesempatan untuk bertemu antar anggota dewan komisaris. Sehingga akan berdampak buruk bagi kinerja keuangan perusahaan. Namun dalam beberapa penelitan lainnya mengungkapkan bahwa dengan semakin meningkatnya anggota dewan komisaris maka kinerja keuangan semakin membaik karena banyaknya ide-ide baru yang strategis demi meningkatkan kinerja keuangan perusahaan. Dengan demikian, hipotesis yang kedua dirumuskan sebagai berikut :

H2 : Ukuran Dewan Komisaris berpengaruh signifikan terhadap Kinerja Keuangan Perusahaan

\section{Pengaruh Konsentrasi Kepemilikan terhadap Kinerja Keuangan Perusahaan}

Hasil penelitian dari Puspitasari dan Ernawati (2010) menunjukan bahwa adanya pengaruh yang positif dari konsentrasi kepemilikan terhadap ROE. Hal ini menunjukan bahwa kepemilikan saham yang terkonsentrasi dapat mengurangi keragaman kepentingan pemegang saham sehingga terjalinnya kerja sama antara pihak manajer dan pemegang saham dalam meningkatkan kinerja keuangan perusahaan. Dengan demikian hipotesis yang ketiga dirumuskan sebagai berikut :

H3 : Konsentrasi Kepemilikan berpengaruh signifikan terhadap Kinerja Keuangan Perusahaan

\section{Pengaruh Ukuran Dewan Komisaris terhadap Kinerja Keuangan Perusahaan}

Semakin banyak anggota dewan komisaris maka akan semakin buruk kinerja keuangan perusahaan. Hal ini disebabkan karena semakin banyak anggota dewan komisaris maka dalam menjalankan peran akan mengalami kendala. Koordinasi antar anggota dewan dalam proses pengambilan keputusan akan sangat sulit dilaksanakan dan prosesnya menjadi lambat karena sulitnya kesempatan untuk bertemu antar anggota dewan komisaris. Sehingga akan berdampak buruk bagi kinerja keuangan perusahaan. Namun dalam beberapa penelitan lainnya mengungkapkan bahwa dengan 
semakin meningkatnya anggota dewan komisaris maka kinerja keuangan semakin membaik karena banyaknya ide-ide baru yang strategis demi meningkatkan kinerja keuangan perusahaan. Dengan demikian, hipotesis yang kedua dirumuskan sebagai berikut :

H2 : Ukuran Dewan Komisaris berpengaruh signifikan terhadap Kinerja Keuangan Perusahaan

\section{Pengaruh Konsentrasi Kepemilikan terhadap Kinerja Keuangan Perusahaan}

Hasil penelitian dari Puspitasari dan Ernawati (2010) menunjukan bahwa adanya pengaruh yang positif dari konsentrasi kepemilikan terhadap ROE. Hal ini menunjukan bahwa kepemilikan saham yang terkonsentrasi dapat mengurangi keragaman kepentingan pemegang saham sehingga terjalinnya kerja sama antara pihak manajer dan pemegang saham dalam meningkatkan kinerja keuangan perusahaan. Dengan demikian hipotesis yang ketiga dirumuskan sebagai berikut :

H3 : Konsentrasi Kepemilikan berpengaruh signifikan terhadap Kinerja Keuangan Perusahaan

\section{Pengaruh Proporsi Hutang terhadap Kinerja Keuangan Perusahaan}

Hasil dari penelitian Martisla dan Meiranto (2013) menunjukan bahwa leverage berpengaruh positif terhadap ROE yang menggambarkan kinerja keuangan. Hal ini menunjukan pihak pemberi pinjaman cenderung untuk melindungi investasi yang ditanamkan dengan terus memantau kinerja keuangan perusahaan. Sehingga semakin tingginya komposisi utang mengakibatkan semakin tinggi pula tuntutan oleh pihak pemberi pinjaman terhadap pihak manajemen untuk meningkatkan kinerja. Dengan demikian hipotesis yang keempat dirumuskan sebagai berikut:

H4 : Komposisi Utang (leverage) berpengaruh signifikan terhadap Kinerja Keuangan Perusahaan

\section{METODE}

Populasi dalam penelitian ini adalah perusahaan manufaktur yang terdaftar di Bursa Efek Indonesia selama periode 2009-2013. Pengambilan sampel dalam penelitian ini menggunakan metode purposive sampling dengan tujuan untuk mendapatkan sampel yang sesuai dengan kriteria sebagai berikut: (1) Perusahaan manufaktur yang terdaftar di BEI dari tahun 2009-2013, (2) Menerbitkan laporan keuangan berturut-turut di BEI, ICMD maupun di media masa di tahun 2009-2013, (3) menggunakan mata uang rupiah dalam laporan keuangan dan laporan tahunan, (4) Adanya kelengkapan data yang dibutuhkan dalam penelitan ini. 


\section{Data Penelitian}

Jenis data yang digunakan dalam penelitian ini menurut cara memperolehnya termasuk dalam jenis data sekunder. Data-data yang digunakan dalam penelitian ini adalah data sekunder yang diperoleh dari situs BEI, Indonesian Capital Market Directory (ICMD), dan situs resmi masing-masing badan usaha. Menurut sifatnya, data dalam penelitian ini termasuk dalam data kuantitatif yaitu data yang berupa angka. Teknik pengumpulan data dilakukan dengan dokumentasi. Data yang dikumpulkan dan digunakan dalam penelitian ini digunakan untuk memecahkan masalah yang sedang diteliti dan menguji hipotesis yang dirumuskan.

\section{Variabel Penelitian}

Variabel yang digunakan dalam penelitian ini meliputi variabel dependen yaitu kinerja keuangan perusahaan yang diproksikan dengan ROE, variabel independen yang terdiri dari kepemilikan manajerial, ukuran dewan komisaris, konsentrasi kepemilikan dan proporsi hutang (leverage) serta variabel kontrol yang terdiri dari komposisi aset tetap dan ukuran perusahaan.

\section{Defenisi Operasional Variabel}

\section{Kinerja Keuangan Perusahaan}

Kinerja keuangan perusahaan merupakan tolak ukur penilaian dari pengelolaan perusahaan. Kinerja keuangan diproksikan dengan ROE. ROE diukur dengan membagi laba bersih dengan total ekuitas.

$$
\text { ROE }=\frac{\text { Laba Bersih }}{\text { Total Ekuitas }}
$$

\section{Kepemilikan Manajerial}

Kepemilikan manajerial adalah kepemilikan saham oleh pihak manajemen perusahaan. Variabel ini dihitung dengan membagi jumlah saham yang dimiliki oleh pihak manajemen dengan jumlah saham yang beredar.

$\mathrm{KM}=\frac{\text { Jumlah saham manajer }}{\text { Jumlah saham yang beredar }}$ 


\section{Ukuran Dewan Komisaris}

Ukuran Dewan Komisaris merupakan jumlah orang yang duduk sebagai anggota dewan komisaris.

UDK = Jumlah anggota dewan komisaris

\section{Konsentrasi Kepemilikan}

Konsentrasi Kepemilikan adalah besarnya kepemilikan saham oleh pemegang saham utama. Konsentrasi kepemilikan diukur dengan membagi jumlah saham yang dimiliki pemegang saham utama dengan jumlah saham yang beredar.

$\mathrm{KK}=\frac{\text { Jumlah saham pemegang saham utama }}{\text { Jumlah saham yang beredar }}$

Proporsi Hutang (Leverage)

Hutang merupakan salah satu sumber pendanaan bagi perusahaan. Proporsi hutang di ukur dengan membagi total liabilitas dengan total aset.

$\mathrm{PU}=\frac{\text { Total Liabilitas }}{\text { Total Aset }}$

\section{Komposisi Aset Tetap}

Komposisi aset tetap merupakan jumlah nilai aset tetap yang digunakan dalam menjalankan perusahaan.

KAT $=\frac{\text { Aset Tetap }}{\text { Penjualan }}$

\section{Ukuran Perusahaan}

Ukuran perusahaan merupakan ukuran besarnya perusahaan dilihat dari tingkat penjualan per tahun.

$\mathrm{UP}=\log$ Penjualan 
HASIL DAN PEMBAHASAN

Tabel 1

Hasil Analisis Regresi Berganda

\begin{tabular}{llccl}
\hline Variabel & Koefisien & t hitung & Sig. & Keterangan \\
& Regresi & $-1,994$ & 0,047 & \\
\hline Konstanta & $-0,131$ & $-0,207$ & 0,836 & $\mathrm{H}_{0}$ diterima \\
Kepemilikan manajerial & $-0,058$ & $-0,670$ & 0,503 & $\mathrm{H}_{0}$ diterima \\
Ukuran Dewan Komisaris & $-0,003$ & 2,930 & 0,004 & $\mathrm{H}_{0}$ ditolak \\
Konsentrasi Kepemilikan & 0,078 & $-2,422$ & 0,016 & $\mathrm{H}_{0}$ ditolak \\
Proporsi Utang & $-0,078$ & $-3,817$ & 0,000 & \\
Komposisi Aset Tetap & $-0,084$ & 4,398 & 0,000 & \\
Ukuran Perusahaan & 0,051 & 0,162 & \\
R Square & & 10,506 & \\
F Hitung & & 0,000 & \\
Sig F & & & \\
\hline
\end{tabular}

\section{Menentukan model MRA}

Berdasarkan output SPSS pada Tabel 2, maka dapat dibuat persamaan regresi berganda sebagai berikut:

$Y=-0,131-0,058 \mathrm{KM}-0,003 \mathrm{UDK}+0,078 \mathrm{KK}-0,078 \mathrm{PU}-0,084 \mathrm{KAT}+0,051 \mathrm{UP}+\mathrm{e}$

Dari persamaan regresi berganda tersebut dapat dijelaskan masing-masing koefisien regresi dalam interpretasi model berikut:

Konstanta $(\mathrm{a})=-0,131$

Nilai konstanta dari persamaan tersebut adalah sebesar -0,131 menunjukkan bahwa jika variabel Kepemilikan Manajerial, Ukuran Dewan Komisaris, Konsentrasi Kepemilikan, Proporsi Utang, Komposisi Aset Tetap, dan Ukuran perusahaan sama dengan nol, maka kinerja keuangan perusahaan sebesar -0,131 satuan.

Koefisien Regresi Kepemilikan Manajerial $(K M)=-0,058$

Nilai Koefisien regresi Kepemilikan Manajerial dari persamaan tersebut sebesar $-0,058$. Nilai koefisien regresi yang negatif menunjukan adanya hubungan yang tidak searah terhadap Kinerja Keuangan Perusahaan (ROE). Jika Kepemilikan manajerial mengalami kenaikan satu satuan, maka ROE mengalami penurunan 0,058 satuan.

Koefisien Regresi Ukuran Dewan Komisaris (UDK) = -0,003

Nilai koefisien regresi Ukuran Dewan Komisaris dari persamaan tersebut sebesar -0,003. Nilai koefisien yang negatif menunjukkan adanya hubungan yang tidak searah terhadap kinerja keuangan perusahaan (ROE). Jika Ukuran Dewan Komisa- 
ris mengalami kenaikan sebesar satu satuan, maka ROE perusahaan mengalami penurunan sebesar 0,003 satuan.

Koefisien Regresi Konsentrasi Kepemilikan=0,078

Nilai koefisien regresi Konsentrasi Kepemilikan dari persamaan tersebut sebesar 0,078. Nilai koefisien yang positif menunjukkan adanya hubungan searah terhadap kinerja keuangan perusahaan (ROE). Jika Konsentrasi Kepemilikan mengalami kenaikan sebesar satu satuan, maka ROE perusahaan mengalami kenaikan sebesar 0,078 satuan.

Koefisien Regresi Proporsi Utang $(P U)=-0,078$

Nilai koefisien regresi Proporsi utang (PU) dari persamaan tersebut sebesar $-0,078$. Nilai koefisien regresi yang negatif menunjukan adanya hubungan berlawanan arah terhadap kinerja keuangan perusahaan. Jika Proporsi utang mengalami kenaikan sebesar satu satuan, maka ROE mengalami penurunan sebesar 0,078 satuan.

Koefisien Regresi Komposisi Aset Tetap = -0,084

Nilai koefisien regresi Komposisi Aset tetap dari persamaan tersebut adalah sebesar -0,084. Nilai koefisien regresi yang negatif menunjukan adanya hubungan yang berlawanan arah dengan kinerja keuangan perusahaan. Jika Komposisi aset tetap mengalami kenaikan sebesar satu satuan, maka ROE mengalami penurunan sebesar 0,084 satuan.

Koefisien Regresi Ukuran Perusahaan $=0,051$

Nilai koefisien regresi ukuran perusahaan dari persahaan tersebut adalah sebesar 0,051. Nilai koefisien regresi yang positif menunjukan adanya hubungan yang searah dengan kinerja keuangan perusahaan. Jika ukuran perusahaan mengalami kenaikan sebesar satu satuan, maka ROE mengalami kenaikan sebesar 0,051 satuan.

Koefisien Determinasi (R2)

Koefisien determinasi digunakan untuk mengukur seberapa jauh kemampuan model dalam menerangkan variasi variabel dependen atau dapat diartikan besar kontribusi variabel kepemilikan manajerial, ukuran dewan komisaris, konsentrasi kepemilikan, proporsi utang secara simultan dalam mmpengaruhi variabel kinerja keuangan perusahaan.

Tabel 2 menunjukkan bahwa keempat variabel kepemilikan manajerial, ukuran dewan komisaris, konsentrasi kepemilikan dan proporsi utang dapat menjelaskan variabel kinerja keuangan perusahaan sebesar nilai $R$ Square 0,162. Hal ini berarti besarnya pengaruh kepemilikan manajerial, ukuran dewan komisaris, konsentrasi kepemilikan, dan proporsi utang dapat menjelaskan kinerja keuanganperusahaan hanya sebesar $16,2 \%$, sedangkan sisanya dijelaskan oleh faktor-faktor lain di luar peneli- 
tian seperti kebijakan hutang, komite audit, dan lain-lain.

\section{Uji Parsial (Uji t)}

Uji t digunakan untuk menguji besarnya pengaruh kepemilikan manajerial, ukuran dewan komisaris, konsentrasi kepemilikan, dan proporsi utang secara individu berpengaruh signifikan terhadap kinerja keuangan perusahaan. Hasil uji t dapat dilihat pada tabel 2 sebagai berikut :

1). Pengaruh kepemilikan manajerial terhadap kinerja keuangan perusahaan

Pada tabel 2 tampak bahwa tingkat signifikansi sebesar 0,836 >0,05, sehingga Ho diterima. Dapat disimpulkan bahwa kepemilikan manajerial tidak berpengaruh secara signifikan terhadap kinerja keuangan perusahaan.

2). Pengaruh ukuran dewan komisaris terhadap kinerja keuangan perusahaan

Pada tabel 2 tampak bahwa tingkat signifikansi sebesar 0,503 $>0,05$. Hal ini menunjukan bahwa Ho diterima. Maka dapat disimpulkan bahwa ukuran dewan komisaris berpengaruh tidak signifikan terhadap kinerja keuangan perusahaan.

3). Pengaruh konsentrasi kepemilikan terhadap kinerja keuangan perusahaan

Pada tabel 2 tampak bahwa tingkat signifikansi sebesar 0,004 $<0,05$. Hal ini menandakan bahwa Ho ditolak. Sehingga dapat disimpulkan bahwa konsentrasi kepemilikan berpengaruh signifikan terhadap kinerja keuangan perusahaan. Arah pengaruh konsentrasi kepemilikan terhadap kinerja keuangan adalah negatif yang menunjukkan bahwa semakin besar tingkat konsentrasi kepemilikan maka akan menurunkan kinerja keuangan yang diproksikan dengan ROE.

4). Pengaruh proporsi utang terhadap kinerja keuangan perusahaan

Pada tabel 2 tampak bahwa tingkat signifikansi sebesar 0,016 $<0,05$. Hal ini menunjukan bahwa $\mathrm{H}_{\mathrm{o}}$ ditolak. Dapat disimpulkan bahwa proporsi utang berpengaruh signifikan terhadap kinerja keuangan perusahaan.

5). Pengaruh variabel lain dari luar terhadap kinerja keuangan perusahaan

Berdasarkan hasil analisis statistik pada tabel 2 tampak bahwa variabel komposisi aset tetap sebagai variabel kontrol memiliki pengaruh signifikan terhadap kontrol lainnya adalah variabel ukuran perusahaan yang diukur dengan log penjualan. Hasil penelitian ini menunjukkan bahwa variabel ukuran perusahaan berpengaruh signifikan terhadap kinerja keuangan perusahaan. Hal ini dapat terjadi karena pada perusahaan dengan ukuran yang besar memiliki sumber daya yang besar sehingga meningkatkan kualitas pelaksanaan corporate govenance. kinerja keuangan perusa- 
haan yang diproksikan dengan ROE. Hasil penelitian menunjukkan semakin besar komposisi aset tetap maka kinerja keuangan perusahaan semakin membaik.

6). Pengaruh Kepemilikan Manajerial terhadap Kinerja Keuangan

Hasil penelitian ini menunjukkan bahwa kepemilikan manajerial berpengaruh tidak signifikan terhadap kinerja keuangan perusahaan. Hasil ini menolak hipotesis pertama dalam penelitian ini yang menyatakan bahwa kepemilikan manajerial berpengaruh signifikan terhadap kinerja keuangan perusahaan. Jika dilihat dari data sekunder yang ada tampak bahwa kepemilikan saham oleh manajer tidak stabil untuk setiap tahun amatan. PT Intan Wijaya International Tbk yang memiliki tingkat kepemilikan manajerial tertinggi yaitu sebesar 37,11\% pada tahun 2009, 2010, dan 2011 tetapi memiliki nilai ROE yang negatif sedangkan pada tahun 2012 dan 2013 memiliki tingkat kepemilikan manajerial sebesar 8,38\% dan nilai ROE yang positif. Setelah dilihat dari laporan keuangan yang diterbitkan, ditemukan bahwa pada tahun 2009, 2010 dan 2011, perusahaan memiliki direktur utama yang tidak mempunyai saham perusahaan. Tetapi pada tahun 2012 dan 2013 perusahaan mengangkat direktur utama baru yang memiliki saham perusahaan sehingga kinerja keuangan pada tahun tersebut membaik. Direktur utama sangat berperan penting dalam pengambilan keputusan. Jika direktur tidak memiliki kepemilikan saham maka direktur tidak optimal meningkatkan kinerja keuangan perusahaan dalam pengambilan keputusan guna meningkatkan kinerja keuangan perusahaan dan menguntungkan pihak pemilik saham. Jika dilihat dari arah pengaruh hasil analisis regresi, penelitian ini menunjukkan bahwa semakin besar kepemilikan manajerial maka kinerja keuangan semakin menurun namun terjadinya tidak signifikan. Hasil penelitian ini berbeda dengan hasil penelitian pada umumnya bahwa semakin tinggi kepemilikan manajerial maka semakin baik kinerja keuangan perusahaan.

Dalam penelitian ini, pengaruh yang tidak signifikan disebabkan karena direktur tidak terlibat langsung dalam kegiatan operasional perusahaan sehingga menyebabkan pengambilan keputusan yang tidak efektif.. Hasil penelitian ini tidak sejalan hasil penelitian yang dilakukan oleh Martsila dan Meiranto (2013) yang mengemukakan bahwa kepemilikan manajerial berpengaruh positif tidak signifikan terhadap kinerja keuangan perusahaan yang diproksikan dengan nilai ROE. Sedangkan hasil penelitian ini mendukung hasil penelitian dari Puspitasari dan Ernawati (2010) yang menemukan bahwa kepemilikan manajerial berpengaruh negatif terhadap kinerja keuangan perusahaan.

\section{7). Pengaruh Ukuran Dewan Komisaris terhadap Kinerja Keuangan}

Ukuran Dewan Komisaris merupakan jumlah anggota dewan yang duduk sebagai dewan komisaris. Variabel ukuran dewan komisaris dalam penelitian ini bep- 
engaruh tidak signifikan terhadap kinerja keuangan perusahaan. Hasil ini menolak hipotesis kedua dari penelitian ini yaitu variabel ukuran dewan komisaris berpengaruh signifikan terhadap kinerja keuangan perusahaan. Jika dilihat dari arah pengaruhnya, hasil penelitian ini menunjukkan bahwa semakin banyak jumlah anggota dewan maka kinerja keuangan perusahaan akan mengalami penurunan. Hal ini disebabkan karena semakin banyak jumlah anggota dewan maka waktu yang diperlukan untuk pengambilan keputusan akan semakin lama karena sulitnya mengatur waktu untuk rapat keseluruhan anggota dewan. Dengan pengambilan keputusan yang kurang optimal akan berdampak pada pencapaian tujuan perusahaan yang lambat. Informasi mengenai peluang bisnis bagi perusahaan yang terlambat disampaikan dalam rapat anggota dewan komisaris menyebabkan peluang tersebut diambil alih oleh perusahaan saingan. Hasil penelitian ini sejalan dengan penelitian Puspitasari dan Ernawati (2010) yaitu ukuran dewan komisaris berpengaruh negatif tidak signifikan terhadap kinerja keuangan yang diproksikan dengan ROE. Namun tidak sejalan dengan penelitian Martsila dan Meiranto (2013) yang menemukan bahwa ukuran dewan komisaris berpengaruh positif signifikan terhadap kinerja keuangan yang diproksikan dengan ROE.

8). Pengaruh Konsentrasi Kepemilikan terhadap Kinerja Keuangan

Konsentrasi kepemilikan merupakan tingkat kepemilikan saham oleh pemegang saham utama. Variabel konsentrasi kepemilikan dalam penelitian ini berpengaruh signifikan terhadap kinerja keuangan perusahaan. Hasil ini menerima hipotesis penelitian ketiga yang menyatakan bahwa konsentrasi kepemilikan berpengaruh signifikan terhadap kinerja keuangan perusahaan. Dilihat dari arah pengaruhnya, konsentrasi kepemilikan berpengaruh positif terhadap kinerja keuangan perusahaan. Semakin besar tingkat konsentrasi kepemilikan maka semakin baik kinerja keuangan perusahaan. Hal ini dapat terjadi karena tingginya tingkat konsentrasi kepemilikan mengakibatkan berkurangnya keragaman kepentingan pemegang saham yang berdampak pada adanya kemudahan kerja sama pihak manajer dan pemegang saham dalam meningkatkan kinerja keuangan perusahaan. Selain itu, proses monitoring dapat dengan mudah dilakukan. Hasil penelitian ini sejalan dengan penelitian yang dilakukan oleh Puspitasari dan Ernawati (2010) serta Martsila dan Meiranto (2013) namun tidak sejalan dengan penelitian dari Shan dan Mclver (2006) serta Leng (2004) yang menemukan bahwa konsentrasi kepemilikan berpengaruh tidak signifikan terhadap kinerja keuangan.

\section{9). Pengaruh Proporsi Utang terhadap Kinerja Keuangan}

Variabel proporsi utang dalam penelitian ini diukur dengan membandingkan total liabilitas dengan total aset. Hasil penelitian ini adalah proporsi utang berpengaruh signifikan terhadap kinerja keuangan yang diproksikan dengan ROE. Hasil ini mendukung hipotesis keempat dari penelitian ini yang menyatakan bahwa proporsi utang 
berpengaruh signifikan terhadap kinerja keuangan perusahaan. Jika dilihat dari arah pengaruhnya, semakin besar proporsi utang perusahaan maka kinerja keuangan perusahaan akan semakin menurun. Hal ini dapat terjadi karena jika utang yang dimiliki oleh perusahaan semakin besar maka beban bunga akan dibayarkan oleh perusahaan juga semakin besar yang berdampak pada penurunan kinerja keuangan perusahaan. Namun jika proporsi utang semakin menurun maka kinerja keuangan perusahaan akan semakin baik karena berkurangnya beban bunga yang akan dikeluarkan oleh perusahaan. Jika dilihat dari hasil analisis deskriptif, tampak bahwa nilai tertinggi dari proporsi utang adalah sebesar 1,3953 oleh PT Sumelindo Lestari Jaya Tbk pada tahun 2013. ROE perusahaan pada tahun 2013 sebesar 0,8752 yakni diatas rata-rata proporsi utang pada tahun tersebut dan merupakan ROE terbaik perusahaan selama periode amatan. Dengan demikian semakin besar proporsi utang maka semakin meningkatkan kinerja keuangan. Hal tersebut dapat terjadi karena dengan semakin besar jumlah utang perusahaan, maka perusahaan akan semakin giat dalam meningkatkan produksi dan penjualan dengan meminimalisasi biaya-biaya kesalahan yang akan berdampak pada peningkatan kinerja keuangan perusahaan sehingga proses pembayaran utang tidak terhambat. Selain itu, dari analisis deskriptif juga terdapat perusahaan dengan proporsi utang yang meningkat namun kinerja keuangannya tidak stabil atau pada tahun tertentu meningkat dan pada tahun tertentu menurun.

Sehingga dari analisis regresi dan deskriptif dapat disimpulkan bahwa proporsi utang berpengaruh tidak signifikan terhadap kinerja keuangan. Jika dilihat dari arah pengaruhnya, penelitian ini tidak sejalan dengan penelitian yang dilakukan oleh Martsila dan Meiranto (2013) namun sama dengan hasil penelitian dari Puspitasari dan Ernawati (2010).

\section{SIMPULAN}

Penelitian ini bertujuan untuk menguji pengaruh kepemilikan manajerial, ukuran dewan komisaris, konsentrasi kepemilikan dan proporsi utang (leverage) terhadap kinerja keuangan perusahaan manufaktur. Penelitian ini menambahkan dua variabel kontrol yaitu komposisi aset tetap dan ukuran perusahaan agar hasil penelitian lebih akurat atau tidak bias. Sampel yang digunakan adalah perusahaan manufaktur yang terdaftar di Bursa Efek Indoesia tahun 2009-2013. Penelitian ini memberikan hasil sebagai berikut :

Kepemilikan manajerial memiliki pengaruh tidak signifikan terhadap kinerja keuangan perusahaan manufaktur. Penelitian ini sejalan dengan penelitian dari Martsila dan Meiranto (2013).

Ukuran dewan komisaris memiliki pengaruh tidak signifikan terhadap kinerja 
keuangan perusahaan manufaktur. Penelitian ini tidak sejalan dengan penelitian Puspitasari dan Ernawati (2010). Konsentrasi kepemilikan memiliki pengaruh signifikan terhadap kinerja keuangan perusahaan manufaktur. Penelitian ini tidak sejalan dengan penelitan Shan dan Mclver (2006) serta Leng (2004). Proporsi utang (leverage) memiliki pengaruh signifikan terhadap kinerja keuangan perusahaan manufaktur. Penelitian ini sejalan dengan Puspitasari dan Ernawati (2010).

Penelitian ini mempunyai keterbatasan, yaitu (1) sampel perusahaan yang kebanyakan tidak memiliki kepemilikan saham oleh manajer sehingga membuat data tidak terdistribusi normal(2) terdapat sampel perusahaan yang memiliki Return on Equity negatif sehingga membuat data tidak terdistribusi normal (3) data tidak terdistribusi normal sehingga harus dilakukan pembuangan data outlier.

Berdasarkan hasil dan keterbatasan penelitian, maka saran yang dapat diberikan kepada peneliti selanjutnya diharapkan dapat meneliti pengaruh corporate governance terhadap kinerja keuangan perusahaan pada sektor selain manufaktur, menambah periode penelitian dan mekanisme corporate governance lainnya yang sekiranya mempengaruhi kinerja keuangan perusahaan agar mendapat hasil yang lebih bervariasi serta mengukur kinerja keuangan dengan rasio keuangan lainnya.

Bagi Investor, diharapkan lebih memperhatikan lebih memperhatikan konsentrasi kepemilikan suatu perusahaan, karena konsentrasi kepemilikan berpengaruh paling signifikan terhadap kinerja keuangan perusahaan, dan juga memperhatikan hal lain diluar variabel penelitian ini seperti umur perusahaan, kebijakan hutang dan pendanaan dalam perusahaan sebagai alat pertimbangan sebelum melakukan pengambilan keputusan untuk investasi.

\section{PUSTAKA ACUAN}

Darmawati, Deni.; Khomsiyah dan Rika Gelar Rahayu, 2005, "Hubungan Corporate Governance dan Kinerja Perusahaan", Jurnal Riset Akuntansi Indonesia, Vol. 8, No. 1, Januari.

Ehikioya, Benjamin I. 2009. "Corporate Governance Structure and Firm Performance in Developing Economies: Evidence from Nigeria". Corporate Governance, Vol. 9 Iss: 3 pp. 231-243

Eisenhardt, Kathleen M. 1989. "Agency Theory: An Assessment and Review". The Academy of Managenet Review, Vol.14, No.1, pp. 57-74

Imam Ghozali. 2011. "Aplikasi Analisis Multivariate dangan Program IBM SPSS 20". Edisi Keenam. Semarang: Badan Penerbit Universitas Diponegoro.

Jensen, Michael C. dan William H. Meckling. 1976. "Theory of the Firm: Managerial 
Behavior, Agency Costs and Ownership Structure". Journal of Financial Economics, Vol. 3, No.4, pp. 305-360

Johnson, A. Richard dan Dean W. Wichern. 2002. "Applied Multivariate Statistical Analysis". Third Edition. Prentice Hall International.

Johnson, Simon; P. Boone; A. Breach; dan E. Friedman. 2000. Corporate governance

in Asian financial crisis. Journal of Financial Economics, 58, hal. 141-186.

Klapper, Leonra F. and. I. Love, 2002, "Corporate Governance, Investor Protection, and Performance in Emerging Markets", World Bank Working Paper, (http://paper.ssrn.com)

La Porta, Rafael; F. Lopez-de-Silanes; A. Shleifer; dan R. Vishny. 2000. Investor

Protection and Corporate Governance. Journal of Financial Economics. 58, hal. 3-27

Leng, Allan C. A. 2004. "The Impact of Corporate Governance Practices on Firms Financial Performance”. ASEAN Economic Bulletin. 21 (December). Pp 308-318

Martsila, Ika dan Wahyu Meiranto. 2013. "Pengaruh Corporate Governance terhadap Kinerja Keuangan Perusahaan". Journal of Accounting Volume 2, Nomor 4, Tahun 2013, pp. 1-14

Nuryaman.2009. "Pengaruh Konsentrasi Kepemilikan, Ukuran Perusahaan, dan Mekanisme Corporate Governance terhadap Pengungkapan sukarela". Jurnal Akuntansi dan Keuangan Indonesia Volume 6- Nomor 1 Juni 2009 pp. 89-116

Puspitasari, Filia dan Endang Ernawati. 2010. "Pengaruh Mekanisme Corporate Governance terhadap Kinerja Keuangan Badan Usaha”. Jurnal Manajemen Teori dan Terapan, Tahun 3, No. 2, Agustus 2010.

Rochbini, Didik. 2008. Arsitektur Hukum Investasi Indonesia. Jakarta : PT. Indeks

Sawir, Agnes. 2001. Analisis Kinerja Keuangan dan Perencanaan Keuangan Perusahaan. Jakarta: Gramedia Pustaka Utama.

Singgih Santoso. 2014. Panduan Lengkap SPSS Versi 20 "Edisi Revisi". Jakarta : PT Elex Media Komputindo.

Shan, George W dan Ron Mclver. 2006. "Corporate Governance Mechanisms and Financial Performance in China:panel data evidence on listed non financial companies". Asia Pacific Business Riview. 17 (July). Pp 301-324

Syofian Siregar. 2013. Metode Penelitian Kuantitatif "Dilengkapi dengan Perbandingan Perhitungan Manual \& SPSS". Jakarta:PT.Kencana.

Weston, J. Fred; Copeland, Thomas E., Managerial Finance. New York: CBS College Publising. 1992. 